\title{
DESIGN OF ACCOUNTING CURRICULUM: THE CASE OF ESTONIA
}

The process of globalization sets new requirements for the professional qualification of accountants and auditors. In the business world globalized investment market demands consistent high quality financial information across borders; investors are looking for a global accounting profession to provide it. There is more pressure on accounting professionals to expand and enhance their knowledge, skills, and abilities beyond what they are currently likely to possess. Providers of accounting education must take into account the changed world and create contemporary curricula.

In Estonia the change from a command to a market economy has inevitably influenced not only the accounting framework but also the entire system of accounting education. It is clear that without a design of accounting curricula it is practically impossible to fulfill requirements of nowadays high quality financial information. Tallinn University of Technology (TUT) holds on the advanced level of accounting education the leading position in Estonia. The accounting curriculum (on the graduate level as well as undergraduate level) is the most popular among all curricula at the Tallinn School of Economics and Business Administration of TUT. It is a joint system, which consists of undergraduate and graduate degree programs. Small sub specializations: for example in financial accounting, managerial cost accounting, taxation and auditing become evident while interpreting the graduate and undergraduate programs as one united system.

The paper explains a new model of accounting curriculum developed at TUT as well as its educational philosophy and principles of designing. It also describes conditions required for development and continuous improvement of competitive curriculum.

Key words: accounting curriculum, accounting education, Estonia

Lehte Alver, Professor in the Tallinn University of Technology, Estonia, e-mail: lehte. alver@ttu.ee

** Jaan Alver, Professor in the Tallinn University of Technology, Estonia, e-mail: jaan.alver@ttu.ee 


\section{Introduction}

Estonia is a small country in the Baltic region of Northern Europe. The territory of Estonia covers $45,227 \mathrm{~km}^{2}$ and the population was 1,286,479 in 01.01 .2013 (referenced by e-stat). In the context of accounting, Estonia is one of the leastknown states in Europe. The Estonian accounting regulation has only a relatively brief history compared to those of some other European countries. In 1918-1940, it was possible to learn accounting in several trade schools all over Estonia. In 1920, the Law Faculty of Tartu University established the Institute (Department) of Commercial Studies. In 1936, the Accounting Department was established at

Tartu University. It has to be noted that in spite of several learning possibilities the quality of the education was quite poor. It can be explained by the fact that there were no good teaching materials and Estonian speaking academics. After incorporating Estonia into the USSR in 1940, and in fact after World War II, the Soviet system of bookkeeping was in use. From 1945 until 1990 the Soviet influence on accounting development (including accounting education development) had been total because Estonia was a part of the former Soviet Union. Under the Soviet period all Estonian institutions of higher education had been conducting the accounting curricula on the basis of a single curriculum designed in Moscow. After declaring the restoration of the independence of the Republic of Estonia in 1990, it became possible to begin the reform of accounting and join the system of accounting of well-developed market-oriented countries.

Each Estonian institution of higher education was given freedom in designing and adopting its own curricula in any field of studies. A variety of programs and courses exist with even greater variations in quality. Due to the absence of official curricula and textbooks, the initiative for the development of these programs has been foremost with individual instructors and institutions.

\section{Ten steps of development of accounting curriculum at Tallinn University of Technology}

Curriculum building is very similar to building a new product. For institutions of higher education, a curriculum is like a product for industrial companies. The following steps must be covered (Nelson, Bailey and Nelson, 1998): study of potential markets; evaluation of raw materials; evaluate resources; study of competition; develop strategy (select your niche); state a mission; design a product; design a production process; implement change and monitor outcomes. Strategic planning is a tool which can help ensure that the change process will be effective. This concept has often been used in curriculum planning. On the basis of the model presented by Hofer and Schendel (1978) the current paper analyzes the current situation in Estonia. 


\subsection{Study of Potential Market}

For creating a new product the potential market must be researched. The rapid development of a large number of micro, small and medium-size enterprises, joint ventures, and the privatization of large state enterprises created an increasing demand for well-educated, highly skilled accountants and auditors. In Estonia there are over 200,000 business entities and governmental units (referenced by e-äriregister) which must follow the Estonian Accounting Act. The auditing firms need new specialists. So the current analysis in Estonia shows that the situation is good because a lot of highly skilled accountants and auditors are needed.

\subsection{Evaluation of Raw Materials}

To be effective for creating a new product the quality of raw materials must be taken into account. The "raw materials" for the curriculum are students. In this area, each institution must carefully consider the demographics of its student body. There are many factors that must be taken into account: the demographic situation in country, the age distribution, mobility, location, and the number transferring to and from other institutions, work experience, commitments outside work, family commitments, and language skills.

The analysis shows that during the 1990s, the demographic situation in Estonia deteriorated. Estonia suffered a decline in its population of about 200,000, caused by a low birth rate (especially during the first half of the decade), and by emigration. The low birth rate influences the possible number of students. In the period between 1991 and 2000, live births registered in Estonia fell from 19,300 to 13,000 per year. Only in 1999 and in 2000 the number of live births has risen slightly, for the first time in eleven years (Demographic, 2012). Despite some limited encouragement in these trends, and an accompanying decline in the number of deaths, the population of Estonia is continuously decreasing. It creates economic problems and raises fundamental questions about the overall sustainability of a distinct Estonian society.

The age analysis must also be taken into account. In 1991, those aged 19 years and under, represented 29 per cent of the Estonian population, and those aged over 60 represented 17 per cent. By the year 2000, the corresponding figures were 25 and 20 per cent, respectively. As the average age of the overall population increases, so does that of working population. This results in a continuous decline in the proportion of the overall population that is still actively at work. This tendency is a big threat for curricula because the possible number of students is decreasing. In 2013, the population of Estonian people aged 15-24 years represented $11.9 \%$ and aged $25-54$ years $41.3 \%$ from total population (Table 1).

Vol. 11, No 3, 2014: 19-32 
Table 1: Age Structure in 2013

\begin{tabular}{|c|c|}
\hline Age & Percentage \\
\hline $0-14$ years & $15.4 \%$ \\
\hline $15-24$ years & $11.9 \%$ \\
\hline $25-54$ years & $41.3 \%$ \\
\hline $55-64$ years & $13.1 \%$ \\
\hline 65 and over & $18.2 \%$ \\
\hline
\end{tabular}

The current situation shows that more than one third of the population is living in Tallinn (over 436,000). This is a good sign for the curriculum because Tallinn University of Technology (TUT) is located in Tallinn.

All the mentioned characteristics are connected with general resources but there are some requirements set up by the university. A precondition for entry into the master's studies is the bachelor's degree awarded upon graduation from an accredited program, or higher education received through diploma studies or applied higher education. The suitable candidates are selected pursuant to the competition requirements established for the candidates. These requirements affect the quality of our "raw material" in a positive way (we receive the best students).

\subsection{Evaluation of Resources}

In a strategic analysis one's own inside resources must be evaluated. The strengths and weaknesses should be evaluated. The following questions could arise: is our teaching staff able to be in line with today's requirements (to teach new subjects)? Has our teaching staff enough knowledge? Do we have the critical mass to establish the curriculum? At what level are the language skills of our teaching staff?

The analysis conducted by the Accounting Department of TUT shows that the situation has deeply changed during last ten years. The average age of the teaching staff was 49 years in 2003 and it is 44 years in 2013. In 2003 the youngest lecturer was 32 years old, and in 2013 it is 28 years. In May 2011 the first doctoral dissertation was defended in the field of managerial accounting and in May 2012 in financial accounting. But still there is a lot to do. The situation in Estonia is not the best. The profession of a university lecturer is not highly valued.

\subsection{Study of Competition}

The nature of competition, market share, and how the institution of higher education reacts to competitive strategies have a significant influence on curricula and other strategic decisions. In Estonia accounting education is conducted at universities, colleges, vocational schools and specialized schools. Accounting as a part of general business education is taught at most Estonian institutions of higher education, which give business education, but there are very few university level educational institutions where accounting specialty has been established. 
A competitive advantage exists when the firm is able to deliver the same benefits as competitors but at a lower cost (cost advantage), or deliver benefits that exceed those of competing products (differentiation advantage). Thus, a competitive advantage enables the firm to create superior value for its customers and superior profits for itself.

Table 2: Comparison of content of Accounting related curricula on graduate level in 2013 (ECTS credits)

\begin{tabular}{|c|c|c|c|}
\hline Institution & EULS & EA & TUT \\
\hline Curriculum & 120 & 120 & 120 \\
\hline \multicolumn{4}{|l|}{ Accounting related courses } \\
\hline Advanced Course in Financial Accounting & 3.5 & 7.5 & 6 \\
\hline Special Accounting Course & 3 & & \\
\hline Accounting Theory & & & 5 \\
\hline Group Accounting & 3 & & 5 \\
\hline Accounting for Nonbusiness Organizations & 3 & & 5 \\
\hline International Accounting & & & 5 \\
\hline Accounting Information Systems & 3 & 4.5 & 3 \\
\hline Financial Reporting and Analysis & 5 & & 6 \\
\hline Managerial Accounting & 3.5 & 2.25 & \\
\hline Strategic Managerial Accounting and Cost Management & & & 4 \\
\hline Cost Accounting & & 2.25 & \\
\hline Auditing & 4 & & 5 \\
\hline Internal Audit & & & 5 \\
\hline Controlling & 4 & & \\
\hline Taxation & & 4.5 & \\
\hline International Taxation & & & 5 \\
\hline Finance and Accounting Communication & & & 3 \\
\hline Social and Environmental Accounting & & & 3 \\
\hline Ethics for Accountants & & & 2 \\
\hline Accounting related courses (compulsory + elective) & $25+7$ & $7.5+13.5$ & $38+24$ \\
\hline $\begin{array}{l}\text { The number of accounting related courses } \\
\text { (compulsory + elective) }\end{array}$ & $7+2$ & $3+4$ & $8+6$ \\
\hline Practical Training (Internship) & 3 & 2 & 1 \\
\hline Master Degree Course Workshop & 3 & 2 & 3 \\
\hline Graduation Thesis & 30 & 25 & 30 \\
\hline Total number of ECTS & 68 & 50 & 96 \\
\hline
\end{tabular}


Cost and differentiation advantages are known as positional advantages since they describe the firm's position in the industry as a leader in either cost or differentiation. That is true for institutions of higher education too but the authors of the current paper are of the opinion that in this case the differentiation is more important to receive a competitive advantage. This is realized by different (better than the competitors have) curricula.

The next step in the study of competition is to study and compare the competing accounting programs: their advantages and disadvantages. There are only three institutions of higher education where the accounting related curriculum has been created for the master's level. These institutions are Estonian University of Life Sciences or EULS (Eesti Maaülikool, 2013), Euroacademy or EA (Euroakadeemia, 2013) and TUT (Tallinna Tehnikaülikool, 2013). In Table 2 above the content of the master's level accounting curricula is shown.

The figures outlined in bold denote compulsory subjects. For comparison purposes some subjects are modified. For example, the EULS has a subject Advanced Topics in Financial and Managerial Accounting with 7 credits but in Table 2 it is presented by two subjects: Advanced Course in Financial Accounting (with 3.5 credits) and Managerial Accounting (with 3.5 credits). The EA has a subject Managerial and Cost Accounting with 4.5 credits but in Table 2 it is presented by two subjects: Managerial Accounting (with 2.25 credits) and Cost Accounting (with 2.25 credits).

It must be marked that the EULS curriculum includes 9 subjects -7 obligatory and 2 elective. The total number of credits related to accounting courses is 37. It must be emphasized that at EULS the accounting and finance curriculum is available only in the form of distance learning. The studied are organized once per month in the weekends and the amount of contact hours is $25 \%$ from regular contact hours.

The EA curriculum includes 7 subjects - 3 obligatory and 4 elective. The total number of credits related to accounting courses is 21 . It must be marked that the specialization is quite weak and it is possible to graduate without graduation thesis, by taking an exam.

TUT has the most advanced curriculum. It includes 14 courses from which 8 are obligatory and 6 are elective. The total number of credits related to accounting courses is 62 .

\subsection{Strategy Development}

In his various books (Porter, 1980; 1985; 1990; 1998) professor Michael Porter has developed three generic strategies that, he argues, can be used singly or in combination to create a defendable position and to outperform competitors, whether they are within an industry or across nations. Porter states that the strategies are generic because they are applicable to a large variety of situations and 
contexts. According to Porter these strategies are (1) overall cost leadership; (2) differentiation; and (3) focus on a particular market niche. The generic strategies provide direction for organizations in designing incentive systems, control procedures, and organizational arrangements. The second generic strategy, differentiation, attempts to make an organization unique in a dimension that is valued by the customer - it means being different than every other organization. Differentiating the product or service, requires an organization to create something about its product or service that is perceived as unique throughout the industry. It involves making organization's products or services different from and more attractive those of its competitors. How to do this depends on the exact nature of industry and of the products and services themselves, but will typically involve features, functionality, durability and support as well as brand image that customers value. It is necessary to emphasize that the qualification of TUT Accounting Department's teaching staff is the highest in Estonia. This has enabled to build up the unique accounting curriculum with deep specialization.

The third generic strategy, the focus strategy, concentrates efforts on a narrow segment of the market. It answers to the question - what knowledge or expertise can you use or develop to add value for your customers that is not available to broad market competitors? Under a focus strategy, an organization focuses its efforts on one particular segment of the market and aims to become well known for providing products/services for that segment. They form a competitive advantage by catering for the specific needs and wants of their niche market. The Accounting Department of TUT has concentrated efforts on master level curriculum.

Porter specifically warns against trying to "hedge your bets" by following more than one strategy. Somewhat different from Porter the authors of this paper, based on their own experience in building up an accounting curriculum conclude that differentiation and focusing sometimes can be combined very successfully.

To create a new curriculum it is necessary to follow all previous steps: study potential markets, evaluate student body, evaluate the faculty staff and other recourses as well as study competition. The main question is: Is this a good product, is this unusual or unique? By examining the current situation in Estonia on the basis of students' research papers and bachelors' thesis the authors of this paper are of opinion that the knowledge about competitors is sufficient. Estonia is a small country where all resources are known. That is why Tallinn School of Economics and Business Administration (TSEBA) of TUT has developed its strategy through differentiation and unique segment of the market. 


\subsection{State the Mission}

A formalized mission statement is essential in the planning process. The mission for TSEBA is to have the best accounting curriculum in the country. It should be emphasized that the Department of Accounting of TUT is the only department in Estonian institutions of higher education who has declared that its graduates must be able to work abroad.

\subsection{Design of Product}

After the fulfillment of steps 5 and 6 the product must be designed. At TUT the accounting specialization represents a sub-curriculum of the Business Administration curriculum at the undergraduate level and one of the curricula at the master's level. Together they form a " $3+2$ " (undergraduate + graduate) Accounting curriculum which in total consists of 25 accounting related courses. The undergraduate part of the Accounting curriculum includes six courses (Introduction to Financial Accounting, Management Accounting, Taxation, Foreign Language for Special Purposes, Internship I and Research Paper) which are obligatory for all business students. In addition, these students who specialize in Accounting must take three compulsory courses (Intermediate Financial Accounting I, Intermediate Financial Accounting II and Cost Accounting) and they have an opportunity to choose Cost Accounting as elective course.

The authors of this paper agree with the position of the American Accounting Association's Accounting Education Change Commission (AECC, 1990) who in its Objectives of Education for Accountants has declared that "specialized accounting education should be offered primarily at the post-baccalaureate level and via continuing education". This vision has been shared by Sundem, Williams and Chironna (1990): "The main change in specialized accounting education is to move it almost entirely to the post baccalaureate level and to continuing education programs. The increased emphasis on breadth and the need to spend time in accounting courses developing basic skills will leave little time for specialization at the underground level".

The accounting curriculum includes six categories of subjects - general studies; basic studies; core studies; special studies; free choice courses; practice (internship) and graduation thesis.

The Figure 1 shows the conceptual model of the accounting curriculum at TUT. At the master's level students must score 120 credits. Every student admitted to a graduate degree program in accounting is required to enroll for all general subjects (total of 10 credits), basic subjects (14 credits), core studies (20 credits), special studies ( 42 credits) and free choice courses ( 4 credits). In total, it is possible to receive 58 credits by taking accounting courses; the master's thesis 
gives additional 30 credits. It means that 88 credits out of 120 ECTS or $73 \%$ are related to accounting.

Figure 1: Conceptual Model of Accounting Curriculum at TUT

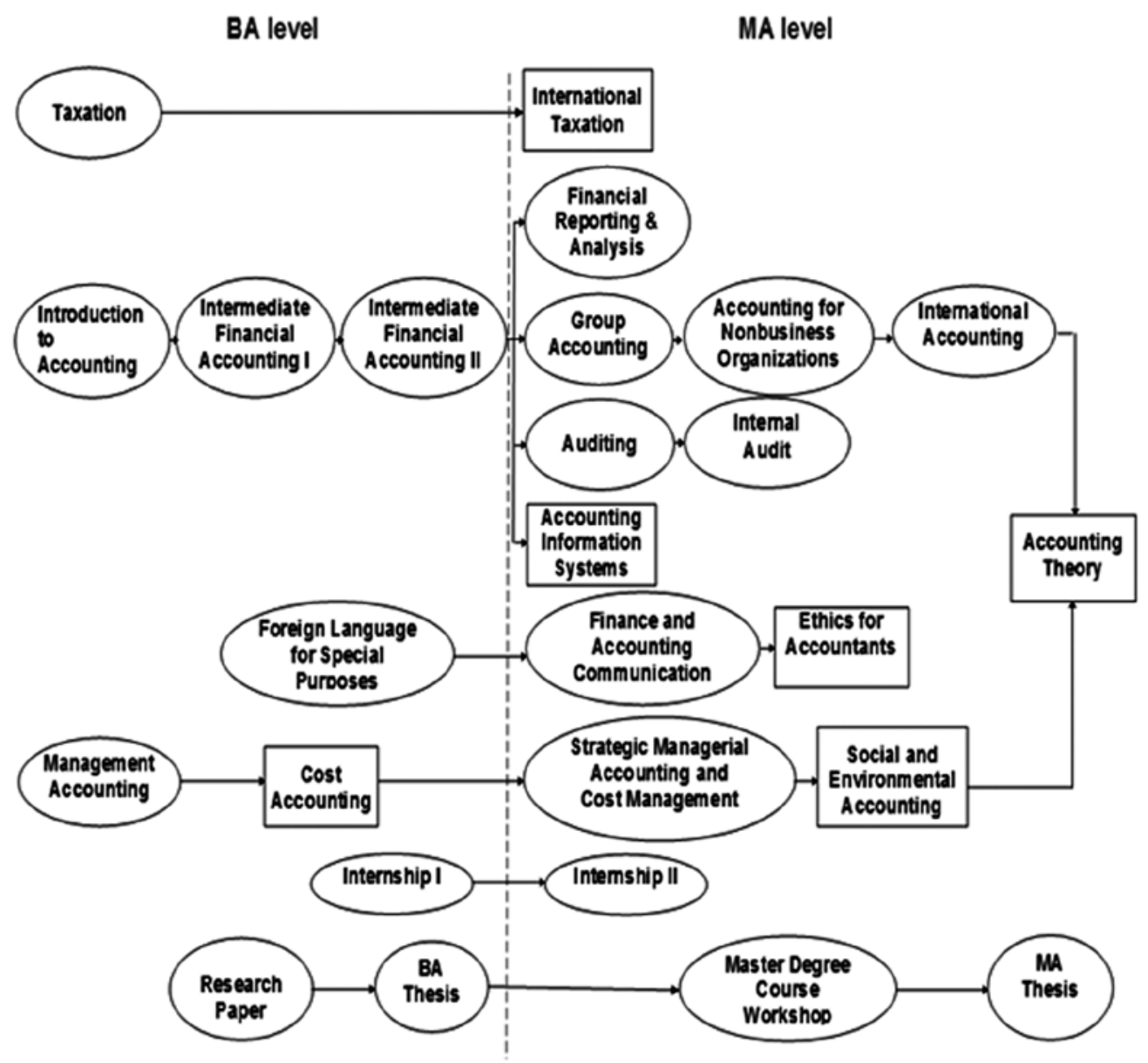

2.8. Designing of Production Process

It should be mentioned that it is possible to find some "small specializations" within TUT Accounting curriculum. For example, Financial Accounting, Management Cost Accounting, Taxation and Auditing (Table 3). It is clear while interpreting the graduate and undergraduate curricula as one united system. It results from the fact that the curriculum is based on the following matrix model as shown in Table 3. 
Table 3: Matrix Model for Accounting Subjects

\begin{tabular}{|c|c|c|c|c|}
\hline \multirow[t]{2}{*}{ Level } & \multicolumn{4}{|c|}{ Modules/subjects } \\
\hline & Financial Accounting & $\begin{array}{c}\text { Management Cost } \\
\text { Accounting }\end{array}$ & Taxation & Auditing \\
\hline Basic & $\begin{array}{l}\text { Introduction to Financial } \\
\text { Accounting }\end{array}$ & Management Accounting & Taxation & Auditing \\
\hline Intermediate & $\begin{array}{l}\text { Intermediate Financial } \\
\text { Accounting I } \\
\text { Intermediate Financial } \\
\text { Accounting II }\end{array}$ & Cost Accounting & & $\begin{array}{l}\text { Internal } \\
\text { Audit }\end{array}$ \\
\hline Advanced & $\begin{array}{c}\text { Group Accounting } \\
\text { Accounting for } \\
\text { Nonbusiness } \\
\text { Organizations } \\
\text { International Accounting }\end{array}$ & $\begin{array}{l}\text { Strategic Managerial } \\
\text { Accounting and } \\
\text { Cost Management } \\
\text { Social and } \\
\text { Environmental } \\
\text { Accounting }\end{array}$ & $\begin{array}{c}\text { International } \\
\text { Taxation }\end{array}$ & \\
\hline Theory & Accounting Theory & Accounting Theory & & \\
\hline
\end{tabular}

\subsection{Implement Change}

The new master's program with a deep accounting specialization started at TUT in 2005 and the first students graduated in 2007. The authors of this paper have monitored the outcomes and analyzed the results. The analysis shows that the students who have entered the master's program from higher education institutions other than TUT sometimes have not the necessary knowledge. For example, in some Estonian institutions of higher education such course as Intermediate Financial Accounting is missing at the undergraduate level. For that reason a new elective course named Advanced Topics in Financial Accounting has been included as an elective in the accounting curriculum at TUT. In addition one compulsory course (Finance and Accounting Communication) and two elective courses (Social and Environmental Accounting and Ethics for Accountants) have been included in fall 2009.

The curriculum development is a continuous process. From fall 2011, the Accounting curriculum on master level has two sub-curricula: Accounting and Auditing. In the Auditing sub-curriculum Auditing course has been split into two compulsory courses: Introduction to Auditing and Auditing of Financial Statements. In addition this sub-curriculum includes one new compulsory course (Governmental Auditing) and one new elective course (Fraud Examination and Forensic Accounting). 


\subsection{Monitor Outcomes}

The last step in development of a new product is to implement an information system to provide feedback on 1) whether the strategic plans are being properly implemented as planned and 2) whether the strategy is yielding the intended results.

The popularity of Finance and Accounting curriculum is the highest at TSEBA. This opinion is supported by admission numbers in Table 4 and rate of competition in Table 5.

Table 4: Admission Numbers

\begin{tabular}{|l|c|c|c|c|c|c|c|c|}
\hline Specialization & $\mathbf{2 0 0 5 / 0 6}$ & $\mathbf{2 0 0 6 / 0 7}$ & $\mathbf{2 0 0 7 / 0 8}$ & $\mathbf{2 0 0 8 / 0 9}$ & $\mathbf{2 0 0 9 / 1 0}$ & $\mathbf{2 0 1 0 / 1 1}$ & $\mathbf{2 0 1 1 / 1 2}$ & $\mathbf{2 0 1 2 / 1 3}$ \\
\hline Economics & $25(16)^{\star}$ & $24(16)$ & $28(16)$ & $29(16)$ & $29(16)$ & $24(16)$ & $18(16)$ & $20(16)$ \\
\hline $\begin{array}{l}\text { Finance and } \\
\text { Accounting }\end{array}$ & $66(13)$ & $68(11)$ & $82(10)$ & $81(10)$ & $98(10)$ & $90(10)$ & $95(15)$ & $81(15)$ \\
\hline $\begin{array}{l}\text { Management } \\
\text { and Marketing }\end{array}$ & $54(12)$ & $51(11)$ & $56(9)$ & $58(9)$ & $68(9)$ & $67(9)$ & $49(9)$ & $69(9)$ \\
\hline
\end{tabular}

${ }^{*}$ number in brackets indicates the number of state-financed student places from the total number of admissions.

Table 5: Rate of Competition to Student Places Formed on the Basis of StateFinanced Education

\begin{tabular}{|l|c|c|c|c|c|c|c|c|}
\hline Specialization & $\mathbf{2 0 0 5 / 0 6}$ & $\mathbf{2 0 0 6 / 0 7}$ & $\mathbf{2 0 0 7 / 0 8}$ & $\mathbf{2 0 0 8 / 0 9}$ & $\mathbf{2 0 0 9 / 1 0}$ & $\mathbf{2 0 1 0 / 1 1}$ & $\mathbf{2 0 1 1 / 1 2}$ & $\mathbf{2 0 1 2 / 1 3}$ \\
\hline Economics & 2.5 & 1.63 & 1.4 & 2.56 & 5.75 & 6.63 & 5.13 & 4.25 \\
\hline $\begin{array}{l}\text { Finance and } \\
\text { Accounting }\end{array}$ & 5.77 & 5.82 & 9 & 9.9 & 21.4 & 20.08 & 19.1 & 17.6 \\
\hline $\begin{array}{l}\text { Management } \\
\text { and Marketing }\end{array}$ & 5.25 & 3.45 & 7.4 & 6.89 & 19.5 & 19.11 & 16.22 & 17.5 \\
\hline
\end{tabular}

${ }^{*}$ from 2009 the candidates have had a possibility to submit two applications on state-funded places.

The accounting sub-curricula (on graduate level as well as on undergraduate level) are the most popular among all (sub)curricula at TSEBA. In 2008 the Accounting curriculum was declared by the international experts to be the best at TSEBA.

\section{Conclusions}

The comparison of the contents of Accounting curricula at the graduate level at the Estonian institutions of higher education shows how different the structure and content of curricula can be inside of a small country. The freedom to design and adopt its own curricula gives an opportunity to be the best provider of accounting education in Estonia. At the same time due to the absence of official 
curricula as well as sufficient number of high-qualified instructors and textbooks in the Estonian language, the quality of accounting education in Estonia can vary.

\section{Literature}

- Demographic problems (2012). Retrieved 28.12.2013 from http://www.estonica.org/en/Problems_facing_Estonia/Demographic_problems/.

- Eesti Maaülikool (2013). Retrieved 28.12.2013 from https://ois.emu.ee/pls/ ois/!tere.tulemast?leht=OK.OK.VA\&id_oppekava=75\&kordi_pealehel=1\&systeemi_ seaded $=3,1,12,1$ \&viida kaudu $=1 \&$ sessioon $=0$.

- Enim nõutud statistika (2013). Retrieved 28.12.2013 from http://www.stat. ee/pohinaitajad.

- Estonia Demographics Profile 2013 (2013). Retrieved 28.12.2013 from http://www.indexmundi.com/estonia/demographics_profile.html.

- Euroakadeemia (2013). Retrieved 28.12.2013 from http://euroakadeemia.ee/media/upload/oppekavad_mai_2013/arijuhtimine__mag_oppekava_ eesti_22052013.pdf.

- Hofer, C. and Schendel, D. (1978). Strategy Formulation: Analytical Concepts. St. Paul: West Publishing Co.

- $\quad$ Nelson, I., Bailey, J. and Nelson, T. (1998). Changing Accounting Education With Purpose: Market Based Strategic Planning for Departments of Accounting. Issues in Accounting Education, 13(2), 301-326.

- Objectives of Education for Accountants. (1990). Accounting Education Change Commission, AAA. Position Statement No. 1. Bainbridge Island. WA: AECC.

- Porter, M. (1985). Competitive Advantage: Creating and Sustaining Superior Performance. New York: The Free Press.

- Porter, M. (1980). Competitive Strategy: Techniques for Analyzing Industries and Competitors. New York: The Free Press

- Porter, M. (1990). The Competitive Advantage of Nations. New York: The Free Press.

- Porter, M. (1998). On Competition. Boston: Harvard Business School.

- Rahvastik (2013). Retrieved 28.12.2013 from http://www.stat.ee/pohinaitajad.

- Sundem, G., Williams, D. and Chironna, J. (1990). The Revolution in Accounting Education. Management Accounting, 72(6), 40-53.

- Tallinna Tehnikaülikool (2013). Retrieved 28.12.2013 from http://www.ttu. ee/majandusteaduskond/majandusteaduskonna-veeb/majanduse-sisseastujale/magistriope-5/oppekavad-31/majandusarvestus-2/.

- Äriregister (2013). Retrieved 28.12.2013 from http://www2.rik.ee/rikstatfailid/failid/tabel.php?url=13_11tg.htm. 
Prof. Lehte Alver,

Tehnološki univerzitet u Talinu, Estonija

Prof. Jaan Alver,

Tehnološki univerzitet u Talinu, Estonija

\section{IZRADA NASTAVNOG PLANA ZA RAČUNOVODSTVO: SLUČAJ ESTONIJE}

\section{S a ž e t a k}

Process globalizacije zahteva nove standarde u vidu profesionalne kvalifikovanosti računovođa i inspektora. U poslovnom sektoru, globalno investiciono tržište zahteva vrlo kvalitetno finansijsko izveštavanje koje premošćava granice; investitori traže da im svetska računovodstvena profesija to ponudi. Postoji pritisak na profesionalce iz oblasti računovodstva da prošire i unaprede svoja znanja, veštine i mogućnosti u poređenju s onima koje trenutno poseduju. Osobe i institucije koje obrazuju u sferi računovodstva treba da uzmu u obzir svet koji se promenio i da izrade moderne nastavne programe.

U Estoniji, promena iz centralizovane u tržišnu privredu je neminovno uticala na računovodstveni okvir kao i na celokupni sistem obrazovanja u domenu računovodstva. Jasno je da je, bez izrade programa nastave iz računovodstva, gotovo nemoguće obezbediti zahteve za današnje visoko kvalitetne finansijske izveštaje. Talinski univerzitet tehnologije (TUT) drži vodeću poziciju u Estonji kad je u pitanju visoko kvalitetno obrazovanje u računovodstvu. Nastavni program (na postdiplomskim i osnovnim studijama) je najpopularniji program od svih ponuđenih na Talinskoj školi ekonomije i poslovne administracije TUT.

To je zajednički program, koji se sastoji od osnovnih do postdiplomskih programa. Male podspecijalizacije: na primer u finansijskom izveštavanju, računovodstvenom praćenju troškova poslovanja, oporezivanju i kontrolama, uočljivo je pri sagledavanju istih da programi postdiplomskih i diplomskih studija pripadaju jednom jedinstvenom sistemu nastave.

Ovaj rad objašnjava novi model računovodstvenog obrazovanja stvoren u TUT-u kao i njihovu obrazovnu filiozofiju i principe u izradi istih. Takođe, objašnjava potrebne uslove za razvoj i konstantno unapređenje nastavnog plana kako bi ostao konkurentan.

Ključne reči: nastavni program za računovodstvo, računovodstveno obrazovanje, Estonija 
